\title{
Please Patiently Pick Per Person-Pedadogue, Pretender, Plagiartist, Pilferer
}

\author{
Mister Seun Ayoade* \\ Independent Researcher, Department of Physiology, Nigeria \\ *Corresponding author: Mister Seun Ayoade, Independent Researcher, Department of Physiology, Oyo State, Nigeria
}

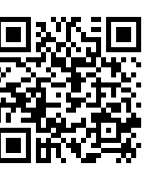

\begin{tabular}{|c|c|}
\hline ARTICLE INFO & ABSTRACT \\
\hline Received: 慧 March 28, 2019 & Ion: Mister Seun Ayoade. Please Patiently Pick Per Person-Pedadogue, Pretender, Pla- \\
\hline Published: 慧 April 08, 2019 & ferer. Biomed J Sci \& Tech Res 16(5)-2019. BJSTR. MS.ID.002917. \\
\hline
\end{tabular}

Peter Piper Picked A Peck of Pickle Pepper. A peck of Pickle Pepper Peter Piper Picked. If Peter Piper Picked a Peck of Pickle Pepper, where's the Peck of Pickle Pepper Peter Piper Picked?

As childish as this tongue twister sounds, it asks a profound question-shouldn't anyone who claims to have done or discovered something be able to provide indisputable evidence? Today when we hear, think or talk of scientific theories or inventions specific names come to mind. Almost like a Pavlovian response we think Darwin when we think evolution, Einstein when we think relativity, Newton when we remember gravity and Zuckerberg when we talk of Facebook. But how many of these individuals actually borrowed and built upon the work of other forgotten or hidden figures? How many of these great names even descended so low as to plagiarize and outright steal the work of others? I myself am a victim of plagiarism. "Cellular Dust" [1] the term I coined to describe the Microzymas was hijacked by some unscrupulous elements [2] and used to describe vesicles barely a year later! [3]. Assuming we were doing some short test in some twilight zone and were given the following questions-

A. The famous formula e=mc square was discovered by:

i) Olinto De Pretto in 1903

ii) Albert Einstein in 1905

B. The principles and experiments that formed the basis of the food preservation technique known as pasteurization were first enunciated and performed by

i) Pierre Bechamp
ii) Louis Pasteur
C. Facebook was created by
i) Cameron and Tyler Winklevoss
ii) Mark Zuckerberg
D. Calculus (integration and differentiation) was invented by
i) Gottfried Leibniz
ii) Isaac Newton
E. The equation for gravitation was discovered by
i) Robert Hooke
ii) Isaac Newton

Did you pick the 'A's or the 'B's in the preceding test? Most people would probably pick the 'B's, but the evidence for picking the 'A's is stronger than you think! It is on record that Albert Einstein spoke and wrote Italian, the language in which Olinto De Pretto published the 62 page paper entitled “Ipotesi dell'Etere nella Vita dell'Universo" [Hypothesis of Aether In The Life Of The Universe] in the Atti del reale Instituto Veneto di Scienze, Lettere ed Arti Volume LXIII [Proceedings of The Royal Veneto Institute of Science, Letters and Arts]. The paper was endorsed by the well-known astronomer Giovanni Schiaparelli. It is theoretically possible that Albert Einstein read Olinto De Pretto's paper and plagiarized it! [4] Olinto De Pretto was shot to death not long after, so Einstein could easily have gotten away with it. For many years Louis Pasteur was a notorious believer in spontaneous generation. In other words when milk became sour 
or food got rotten it was the food itself that had created the germs just like that! It took the experiments of the Professor of Medicine and Chemistry Antoine Pierre Bechamp to prove that the germs came from the air, not the food. So, if you sealed the food in an air tight container you could slow down or stop the rot.

Hear the Professor in his Own Words: "I will now describe the fundamental experiment, the results whereof have completely changed the aspect of science with regard to the relations of chemistry and physiology with fermentation, such as they were still imagined to be at the end of the year 1857, after the theory of Cagniard de Latour in relation to yeast had been rejected. In 1854 it was conceded that cane sugar dissolved in water altered of itself and became transformed into what is called invert sugar, because the solution which deviated the plane of polarization to the right deviated it to the left after the alteration. The inverted sugar was also called grape sugar. The phenomenon of this alteration was called inversion. With the reference to the other researches I resolved to verify the fact and in the month of May 1854, I left to themselves in a closed flask, in the presence of a small volume of air, at ordinary temperature, in a diffused light some aqueous solutions of pure cane sugar. After several months I found that the sugar solutions in pure distilled water were partly inverted. At the beginning of 1855 I published the observations as a verification of the admitted fact, but I mentioned at the same time the presence of a mould in the inverting liquor.

It is not an unusual thing to see moulds to appear in aqueous solutions of the most diverse substances, that was why, in the then state of science and of the contradictory assertions regarding the experiments of Schwann, I would not assert anything beyond the fact. I noted merely that in the solutions to which I had added chloride of calcium, or chloride of zinc, the inversion had not taken place and no mould had appeared. To find an explanation of these differences I made various experiments, commencing in 1855 and continued them to the month of December 1857. Among these experiments, all accordant with one another, I select two, because, reducing the problem to its simplest expression, they leave no room for doubt concerning the legitimacy of the conclusions I deduced from them- the first conclusion was that: the solution of cane sugar in distilled water remains indefinitely unchanged when, having been boiled, it is preserved in an absolutely full closed vase. The second was: the same solution, whether boiled or not, left in a vessel in the presence of a limited volume of air permits the appearance of colourless moulds, generally myellinated, and the solution becomes completely inverted in the course of time, while the liquor reddens litmus paper, that is to say, becomes acid. To prove that the volume of air left in the closed flask has nothing to do with the inversion it suffices to add beforehand a small quantity of creosot..these two experiments demonstrated to me clearly that the presence of the air was essential for the inversion to take place and for the moulds to be born.... [5].

A few years later "Pasteurization" took off. In all fairness, Pasteurization ought to be called Bechampization!

It has been reported that the prototype of Facebook was actually invented by the famous Olympian Winklevoss twin brothers, who hired Zuckerberg-who then pulled the rug out from under them. It is on record that the Winklevoss brothers took Mark Zuckerberg to court and were actually awarded millions of dollars in damages! [6]. That Liebniz and Newton both invented calculus is not disputed. The controversy is who discovered it first. What is certain is that the dy-dx system used today was the notation invented by Leibniz. The clumsy dotted x notation advocated by Isaac Newton is dead as a dodo! "Newton's" equation of gravitation is identical to the earlier published inverse square law used for sound in a gas. The law is no different from Coulomb's equation for electrostatics either. It takes no stretch of the imagination to suspect Isaac Newton "borrowed" the law from Robert Hooke. It is well documented, the intense hatred Newton had for Hooke. Newton once had Hooke's portrait destroyed, not merely removed, when Isaac Newton became head of The Royal Society. In that age before photography existed, the result is that today no one knows for sure what Robert Hooke looked like! [7]. The bottom line is that scientists and inventors are human tooand subject to all the foibles, jealousies, hatred and pettiness that plague the holoi polio [8]. The beauty and genius of the peer review process and recourse to the courts and the justice system is what will inevitably ever separate the pedadogue, plagiarist, pretender and pilferer!!

\section{References}

1. Mister S A (2017) Koch's Postulates and Germ Terrain Dualism; Cellular Dust as Yet another Term for Microzymas. JOJ Nurse Health Care 5(4): 555666.

2. Amanda Silva Brun, Gabriel Rahmi (2018) "Cellular dust" provides new hope for egenerative medicine.

3. (2018) CNRS, Cellular dust' provides new hope for regenerative medicine. ScienceDaily.

4. $\mathrm{E}=\mathrm{mc}^{2}=$ De Pretto Not Einstein by Anthony Parente.

5. A Bechamp (1912) Blood and Its Third Anatomical Element. Kessinger Legacy Reprints, p. 11-13.

6. How Winklevoss twins used $\$ 11 \mathrm{~m}$ Facebook payout to become world's first Bitcoin billionaires. Technology Intelligence.

7. Gal O, Chen Morris (2005) The Archaeology of the Inverse Square Law: (1) R History of Science 43(4): 391-414.

8. Alasdair Wilkins (2012) Was Robert Hooke really the greatest asshole in the history of science? 


\section{ISSN: 2574-1241}

DOI: 10.26717/BJSTR.2019.16.002917

Mister Seun Ayoade. Biomed J Sci \& Tech Res

(C) This work is licensed under Creative

Submission Link: https://biomedres.us/submit-manuscript.php

$\begin{array}{ll}\text { BIOMEDICAL } & \text { Assets of Publishing with us } \\ \text { RESEARCHES } & \text { Global archiving of articles } \\ & \text { - Immediate, unrestricted online access } \\ & \text { - Rigorous Peer Review Process } \\ \end{array}$

